\title{
A minimally invasive approach for atrial and ventricular sew-on epicardial lead placement
}

Joseph R. Nellis, MD, MBA, ${ }^{\mathrm{a}, \mathrm{b}}$ Mohammed K. Alsarraj, BS, ${ }^{\mathrm{b}}$ Jude S. Sauer, MD, ${ }^{\mathrm{c}}$ Jacob A. Klapper, MD, ${ }^{\mathrm{a}, \mathrm{d}}$ Salim F. Idriss, MD, PhD, ${ }^{\text {e,f }}$ and Joseph W. Turek, MD, MBA, PhD, ${ }^{\mathrm{a}, \mathrm{b}, \mathrm{d}, \mathrm{f}}$ Durham, NC, and Victor, NY

From the ${ }^{\mathrm{a}}$ Department of Surgery, Divisions of ${ }^{\mathrm{d}}$ Cardiothoracic Surgery and ${ }^{\mathrm{e}}$ Cardiology and Electrophysiology, ${ }^{\mathrm{e}}$ Pediatric and Congenital Heart Center, Duke University Hospitals, Durham, NC; and ${ }^{\mathrm{b}}$ Duke Congenital Heart Surgery Research \& Training Laboratory, Durham, NC; and ${ }^{\mathrm{c}}$ LSI Solutions, Victor, NY.

Disclosures: Dr Sauer is the founder and CEO of LSI Solutions and worked with the surgical team to develop the tools necessary to complete this procedure. The authors maintained full control over the case report and acknowledge their responsibility for its design, analysis, honesty, and accuracy. All other authors reported no conflicts of interest.

The Journal policy requires editors and reviewers to disclose conflicts of interest and to decline handling or reviewing manuscripts for which they may have a conflict of interest. The editors and reviewers of this article have no conflicts of interest.

Received for publication Feb 13, 2021; accepted for publication Feb 19, 2021; available ahead of print March 1, 2021.

Address for reprints: Joseph W. Turek, MD, PhD, Division of Cardiothoracic Surgery, Department of Surgery, Duke University Hospital, 2301 Erwin Rd, DUMC 3474, Durham, NC 27710 (E-mail: joseph.turek@duke. edu).

JTCVS Techniques 2021;7:245-8

2666-2507

Copyright (C 2021 The Authors. Published by Elsevier Inc. on behalf of The American Association for Thoracic Surgery. This is an open access article under the CC BY license (http://creativecommons.org/licenses/by/4.0/).

https://doi.org/10.1016/j.xjtc.2021.02.025

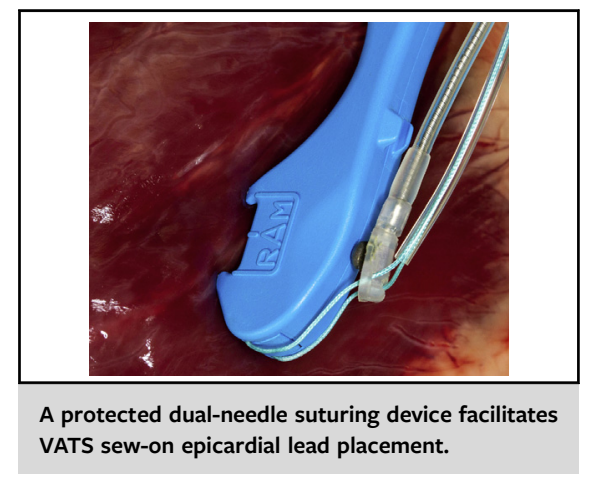

CENTRAL MESSAGE

Atrial and ventricular VATS sew-

on epicardial leads are possible.

This approach provides tradi-

tional lead durability and avoids

the risks associated with placing

screw-in leads into the thin

atrium.

Permanent pacemaker (PPM) placement in pediatric paSee Commentaries on pages 249 and 251. tients is rare. Indications for permanent pacing in children include congenital and postsurgical atrioventricular block, symptomatic sick sinus syndrome, and select neuromuscular disorders. ${ }^{1,2}$ PPMs are traditionally placed using transvenous systems in adults and larger children. However, young children are often not suitable candidates due to their size or history of congenital cardiac surgery.

Epicardial lead placement is an alternative approach for patients who may not otherwise be candidates for transvenous systems. Traditionally, epicardial leads are placed through a median sternotomy during a larger operation, thoracotomy, partial sternotomy, or a subxiphoid incision. ${ }^{3,4}$ Screw-in epicardial leads exist; however, placement is typically limited to the ventricle and durability is reduced. Herein we describe a technique for placing atrial and ventricular sew-on epicardial leads through a minimally invasive video-assisted thoracoscopic surgery (VATS) approach in 5 children.

\section{METHODS}

\section{Patient Selection}

In this series, VATS epicardial pacing was performed due to patient size, complex congenital heart disease, and the absence of additional procedures at the time of intervention. The preferred approach for pacing in infants and

children at our institution, particularly in those with congenital heart defects, is dual-chamber epicardial pacing with a plan for future conversion to a transvenous system when the child is large enough if the cardiac

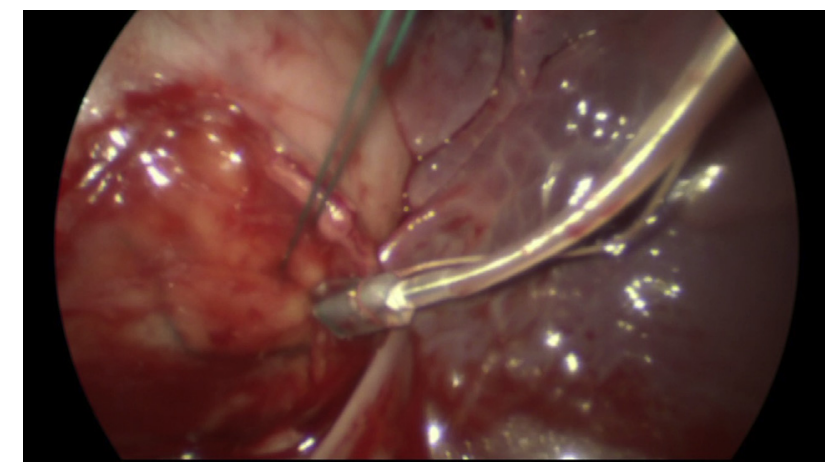

VIDEO 1. Placement of a left ventricular video-assisted thoracoscopic surgery sew-on epicardial lead in a 9-year-old girl with history of previously repair double outlet right ventricular and interrupted aortic arch, complicated by complete heart block requiring permanent pacemaker, who is now undergoing lead exchange following fracture. Video available at: https://www.jtcvs.org/article/S2666-2507(21)00177-2/fulltext. 


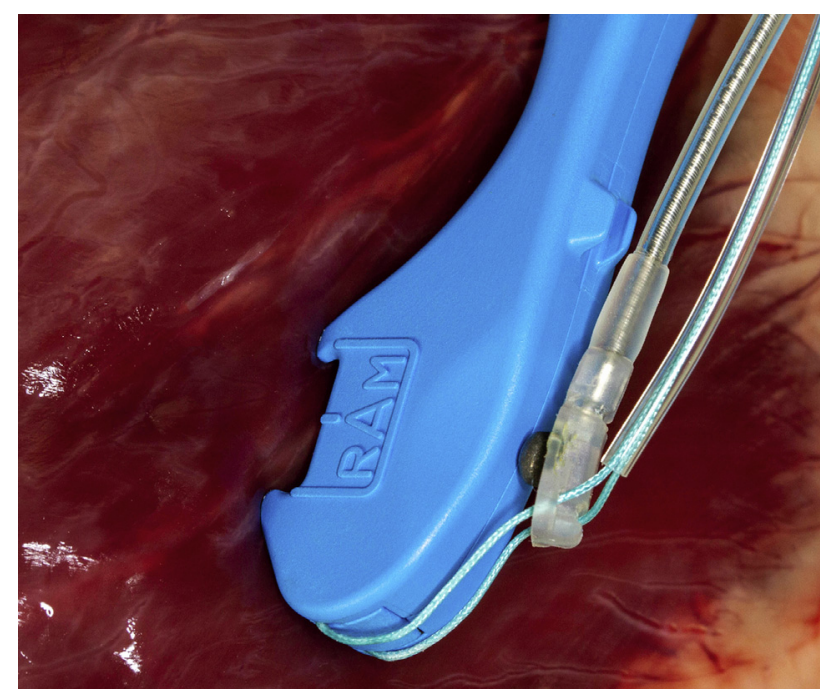

FIGURE 1. A protected dual-needle suturing device facilitates videoassisted thoracoscopic surgery sew-on epicardial lead placement.

anatomy is appropriate. Institutional review board waived consent for this study on May 19, 2020 (Pro00101549).

\section{SURGICAL TECHNIQUE}

After informed consent was obtained, patients were brought into the operating room, placed under general anesthesia and selectively intubated allowing for isolated single lung ventilation. The patient was then placed in right or left semilateral decubitus position depending on the laterality of the planned lead placement. Single lung ventilation was initiated and 35 -mm ports were placed in the fifth, seventh, and ninth intercostal spaces along the left posterior axillary line or right posterior axillary line to provide retraction, instrumentation, and visualization, respectively (Video 1). The pericardium was opened sharply along the posterior aspect using endoscopic scissors, taking care to avoid the phrenic nerve. Steroid-eluting bipolar leads (Medtronic 4968; Medtronic, Minneapolis, Minn) were loaded onto a commercially available, dual-needle suturing device (Figure 1) (RAM; LSI Solutions, Victor, NY). The RAM device was used to simultaneously place 2 bites of a 3-0 suture in horizontal mattress fashion, securing the leads onto the ventricle or atrium. Sutures were then fastened with a titanium fastening device (Cor-Knot; LSI Solutions). The leads were tested, and if satisfactory, a tunnel was made from the generator pocket through the diaphragm under thoracoscopic visualization, and the opposite ends of the leads were passed to the generator pocket. If necessary, the generator was exchanged, and the leads tested again. A single chest tube was then placed, and all incisions were closed in 3 layers. Patients were extubated in the operating room and recovered in the intensive care unit.

Pain scores represent the average patient reported pain (score, 1-10) based on nursing flow sheets during a 24hour period. Total morphine equivalents per day were calculated using previously published conversion factors. ${ }^{5}$

\section{RESULTS}

Five patients underwent VATS sew-on epicardial lead placement between May and September 2018. Patient ages ranged from 9 to 11 years with a median weight of $31 \mathrm{~kg}$ (interquartile range, $28-45 \mathrm{~kg}$ ) and 2 prior median sternotomies (Table E1). Four patients successfully underwent minimally invasive sew-on epicardial lead placement. One patient with hypoplastic left heart syndrome and sinus

TABLE 1. Perioperative data for video-assisted thoracoscopic surgery (VATS) epicardial lead placement

\begin{tabular}{|c|c|c|c|c|c|c|c|c|c|}
\hline Patient & $\begin{array}{l}\text { Date of } \\
\text { surgery }\end{array}$ & Procedure performed & $\begin{array}{l}\text { Single lung } \\
\text { ventilation } \\
\text { time (min) }\end{array}$ & $\begin{array}{l}\text { Operative } \\
\text { time (min) }\end{array}$ & $\begin{array}{l}\text { Nights in } \\
\text { ICU }\end{array}$ & $\begin{array}{l}\text { Nights in } \\
\text { hospital }\end{array}$ & $\begin{array}{l}\text { Average pain } \\
\text { POD } 1 \\
\text { (ME Req) }\end{array}$ & $\begin{array}{l}\text { Average pain } \\
\text { POD } 3 \\
\text { (ME Req) }\end{array}$ & $\begin{array}{c}\text { Average pain } \\
\text { at D/c } \\
\text { (ME Req) }\end{array}$ \\
\hline 1 & $5 / 11 / 18$ & VATS RA lead & 143 & 203 & 1 & 3 & $3.2(5)$ & \multicolumn{2}{|c|}{$0(0)$} \\
\hline 2 & $2 / 22 / 18$ & $\begin{array}{l}\text { VATS LV lead placement } \\
\text { with generator exchange }\end{array}$ & 102 & 162 & 2 & 3 & $3.5(47.5)$ & \multicolumn{2}{|c|}{$0.5(0)$} \\
\hline 3 & $9 / 20 / 18$ & $\begin{array}{l}\text { VATS LA and LV lead } \\
\text { placement with } \\
\text { generator replacement }\end{array}$ & 144 & 275 & 2 & 9 & $1.3(4)$ & $0(0)$ & $0(0)$ \\
\hline 4 & $9 / 27 / 18$ & $\begin{array}{l}\text { VATS to thoracotomy LA } \\
\text { and LV lead placement } \\
\text { with generator placement }\end{array}$ & 311 & 355 & 1 & 4 & $3.8(29.8)$ & $3.8(13.8)$ & $2(0)$ \\
\hline 5 & $9 / 27 / 18$ & $\begin{array}{l}\text { VATS LA and LV lead } \\
\text { placement with generator } \\
\text { placement }\end{array}$ & 35 & 159 & 1 & 4 & $4.3(30)$ & $0(12)$ & $0(9)$ \\
\hline Median & & & 143 & 203 & 1 & 4 & $3.2(23)$ & $0.9(5)$ & $0.5(2)$ \\
\hline
\end{tabular}


TABLE 2. Lead data following video-assisted thoracoscopic surgery epicardial lead placement

\begin{tabular}{|c|c|c|c|c|c|c|c|c|c|c|}
\hline \multirow[b]{3}{*}{ Patient } & \multicolumn{5}{|c|}{ Perioperative lead data } & \multicolumn{5}{|c|}{ Lead data at follow-up } \\
\hline & \multirow[b]{2}{*}{ POD } & \multicolumn{2}{|c|}{ Impedance (Ohms) } & \multicolumn{2}{|c|}{ Threshold (V) } & \multirow[b]{2}{*}{ POD } & \multicolumn{2}{|c|}{ Impedance (Ohms) } & \multicolumn{2}{|c|}{ Threshold (V) } \\
\hline & & Atrial & Ventricle & $\overline{\text { Atria }}$ & $\overline{\text { Ventricle }}$ & & Atrial & Ventricle & $\overline{\text { Atria }}$ & Ventricle \\
\hline 1 & 3 & 476 & - & 0.375 & - & 738 & 436 & - & 0.5 & - \\
\hline 2 & 0 & - & 513 & - & 2.25 & 788 & - & 532 & - & 2.25 \\
\hline 3 & 4 & 742 & 636 & 1.625 & 2.5 & 379 & 1069 & 611 & 1.125 & 2 \\
\hline 4 & 0 & 790 & 974 & 1.5 & 1.8 & 316 & 570 & 399 & 1.625 & 2.5 \\
\hline 5 & 1 & 912 & 722 & 1.25 & 1.375 & 417 & 608 & 532 & 0.75 & 1.5 \\
\hline Median & & 766 & 679 & 1.37 & 2.0 & 417 & 589 & 532 & 0.9 & 2.1 \\
\hline
\end{tabular}

$P O D$, Postoperative day; $V$, volts.

node dysfunction following staged palliation was converted to a minithoracotomy due to dense adhesions. Patients spent a median of 1 night in the intensive care unit and a total of 4 nights in the hospital (Table 1).

At a median 417 days follow-up (interquartile range, 379-738 days), atrial and ventricular lead impedance and voltage remained stable (Table 2). No phrenic nerve injury, surgical site infections, or musculoskeletal deficits were noted at the time of follow-up.

\section{CONCLUSIONS}

For select patients requiring PPM placement who are not candidates for transvenous systems, VATS sew-on epicardial lead placement is a minimally invasive option. Performed through $35-\mathrm{mm}$ port sites, this approach provides single- or dual-chamber pacing options without the need for a partial sternotomy or thoracotomy. Within this select group of patients, there are no contraindications that we have identified. The largest limitations to this approach are the size of the working field and a surgeon's ability to operate thoracoscopically. Early trends in our series suggest that this approach is not associated with increased transfusion requirements, lengths of stay, postoperative pain, or complications, and it may serve as a useful alternative to screw-in lead placement in select patients.

\section{References}

1. Singh HR, Batra AS, Balaji S. Pacing in children. Ann Pediatr Cardiol. 2013;6:46-51.

2. Epstein AE, DiMarco JP, Ellenbogen KA, Estes NA III, Freedman RA, Gettes LS et al. ACC/AHA/HRS 2008 guidelines for device-based therapy of cardiac rhythm abnormalities: a report of the American College of Cardiology/American Heart Association task force on practice guidelines (writing committee to revise the ACC/AHA/NASPE 2002 guideline update for implantation of cardiac pacemakers and antiarrhythmia devices) developed in collaboration with the American Association for Thoracic Surgery and Society of Thoracic Surgeons. Circulation. 2008; 117:e350-408.

3. Cohen MI, Bush DM, Gaynor JW, Vetter VL, Tanel RE, Rhodes LA. Pediatric pacemaker infections: twenty years of experience. J Thorac Cardiovasc Surg. 2002;124:821-7.

4. Haight PJ, Stewart RE, Saarel EV, Pettersson GB, Najm HK, Aziz PF. Lateral thoracotomy for epicardial pacemaker placement in patients with congenital heart disease. Interact Cardiovasc Thorac Surg. 2018;26:845-51.

5. Centers for Disease Control and Prevention. CDC guideline for prescribing opioids for chronic pain. Available at: https://www.cdc.gov/drugoverdose/ prescribing/guideline. Accessed August 1, 2020. 
TABLE E1. Descriptive characteristics of male (M) and female (F) patients undergoing video-assisted thoracoscopic surgery epicardial lead placement

\begin{tabular}{|c|c|c|c|c|c|}
\hline Patient & Age (y) & Sex & Weight (kg) & Indications & Prior operations \\
\hline 1 & 9 & $\mathrm{~F}$ & 59 & $\begin{array}{l}\text { Maternal lupus, } \mathrm{CHB}, \\
\text { pacemaker syndrome now } \\
\text { requiring atrial pacing }\end{array}$ & $\begin{array}{l}\text { PPM via MS 2008, generator } \\
\text { replacement } 2008, \text { left } \\
\text { thoracotomy } 2011 \text { due to } \\
\text { RV lead fracture }\end{array}$ \\
\hline 2 & 9 & F & 45 & $\begin{array}{l}\text { DORV, interrupted aortic arch } \\
\text { repair, CHB requiring PPM } \\
\text { now with poor LV lead } \\
\text { conduction }\end{array}$ & $\begin{array}{l}\text { MS 2008, PPM via repeat MS } \\
\text { 2008, generator } \\
\text { replacement } 2013 \text {, revision } \\
\text { to dual-chamber pacing via } \\
\text { MS after lead fracture } 2014\end{array}$ \\
\hline 3 & 6 & $\mathrm{~F}$ & 19 & $\begin{array}{l}\text { Trisomy } 21, \text { AV canal repair, } \\
\text { CHB requiring PPM, } \\
\text { infected leads and } \\
\text { generator requiring } \\
\text { replacement }\end{array}$ & $\begin{array}{l}\text { MS 2011, PPM 2011, pMS } \\
2018 \text { for lead fracture and } \\
\text { generator exchange, redo } \\
\text { pMS } 2018 \text { for lead and } \\
\text { generator removal due to } \\
\text { infection }\end{array}$ \\
\hline 4 & 11 & $\mathrm{~F}$ & 31 & $\begin{array}{l}\text { HLHS, sinus node } \\
\text { dysfunction, symptomatic } \\
\text { bradycardia, and syncope } \\
\text { requiring PPM }\end{array}$ & $\begin{array}{l}\text { Norwood MS 2007, Glenn } \\
\quad \text { MS 2007, Fontan MS } 2011\end{array}$ \\
\hline 5 & 9 & M & 28 & $\begin{array}{l}\text { Congenital CHB with poor } \\
\text { functional status and } \\
\text { inability to complete } \\
\text { exercise testing due to } \\
\text { fatigue }\end{array}$ & None \\
\hline
\end{tabular}

